\title{
KAJIAN KARAKTERISTIK OBJEKTIF DAN SUBJEKTIF TUAK AREN (Arenga pinnata) BERDASARKAN LAMA WAKTU PENYIMPANAN
}

\section{A. A. Ayu Trisna Pradnyandari ${ }^{1}$, I Gusti Ayu Sri Dhyanaputri ${ }^{2}$., I Nyoman Jirna ${ }^{3}$}

\begin{abstract}
Palm tuak is one of the traditional drink that is usually consumed by majority people in Bali. Tuak palm is produced from fermented palm juice. The fermentation process makes sucrose contained in palm juice will turn into alcohol and continues to acetic acid. The aim of this research is to know the characteristic objective and subjective palm tuak (Arenga pinnata) based on the storage time. The method in this research was quasi experiment design. The samples of palm tuak were stored at room temperature $\left(24-30^{\circ} \mathrm{C}\right)$ on the first day to fifth day. This research was conducted by measuring characteristics objective and subjective at palm tuak, determination of ethanol's concentration by gas chromatography (GC), determination of the $\mathrm{pH}$ by $\mathrm{pH}$ stick, determination of total acid by titration method, and organoleptic test by acceptance test method. The results showed that the ethanol content obtained during time storage of first to fifth day are 8,1512\%, 8,234\%, 9,117\%, 10,6214\%, dan $11,615 \%$ respectively. The $\mathrm{pH}$ was determined is 4 . While total acid obtained during time storage of first to fifth day are 0,321\%,0,421\%,0,433\%, 0,472\%, dan 0,480\%. The result of organoleptic test palm tuak showed that palm tuak that were stored on the first day are the most preferred among the others in terms of taste, color, and aroma.
\end{abstract}

Keywords : ethanol's concentration, total acid, organoleptic test, palm tuak, storage time

\section{PENDAHULUAN}

Budaya mengonsumsi minuman

beralkohol sudah menjadi kebiasaan masyarakat, selain sebagai pelengkap dalam setiap perayaan pesta, minuman ini juga dikonsumsi dengan alasan tradisi atau adat. Minuman beralkohol adalah minuman yang mengandung etanol. Minuman ini diproses dari bahan hasil pertanian yang mengandung karbohidrat dengan cara fermentasi dan destilasi atau fermentasi tanpa destilasi. Fermentasi dapat terjadi dengan cara memberikan perlakuan terlebih dahulu atau tidak, menambahkan bahan lain atau tidak, maupun diproses dengan cara mencampur konsentrat dengan etanol atau dengan cara pengenceran minuman mengandung etanol $^{1}$.

Beberapa jenis minuman beralkohol yang biasa dikonsumsi oleh

\footnotetext{
1.,2.3., Jurusan Analis Kesehatan Poltekkes Denpasar Korespondensi : A. A. Ayu Trisna Pradnyandari ${ }^{1}$, Jurusan Analis Kesehatan, Poltekes Denpasar, Jalan Sanitasi No. 1 Sidakarya, Denpasar-Bali 80224, Indonesia.

Telp. +62-361-710 527, Fax. +62-361-710 448

Email : meditoryjournal@gmail.com
} 
A. A. Ayu Trisna Pradnyandari, dkk., Kajian Karakteristik Objektif Dan Subjektif Tuak Aren (Arenga pinnata) Berdasarkan Lama Waktu Penyimpanan

masyarakat yaitu bir, arak, vodka, wine, whisky, tuak dan lainnya. Tuak merupakan salah satu minuman yang termasuk ke dalam golongan alkohol yang diperoleh dari hasil fermentasi dari bahan minuman atau buah yang mengandung gula. Tuak terdapat di Indonesia dan tersebar hampir di seluruh wilayah kepulauan Nusantara. Tuak dibuat dari sadapan air bunga pohon aren (jake), kelapa (nyuh), dan lontar (ental/siwalan). Tuak aren adalah salah satu minuman tradisional yang biasa dikonsumsi oleh masyarakat di daerah Bali. Tuak aren dihasilkan dari nira aren yang difermentasikan

Tuak aren yang dikonsumsi masyarakat hanya dalam jangka waktu yang relatif singkat yaitu pendiaman selama 1-2 hari yang digunakan sebagai minuman segar, setelah 2 hari minuman ini akan dimanfaatkan sebagai cuka. Selama pendiaman tersebut proses fermentasi akan tetap berlangsung. Proses fermentasi yang berlangsung menyebabkan sukrosa yang terdapat di dalam nira akan berubah menjadi alkohol dan berlanjut menjadi asam asetat.

Penelitian tentang kajian kadar etanol dan asam asetat dalam cairan nira siwalan (Borassus flabellifer linn) menggunakan metode gas kromatografi

METODE menunjukkan bahwa kadar etanol hasil pendiaman yang diperoleh selama 10 jam, 34 jam, 58 jam, 82 jam, 106 jam, 130 jam dan 154 jam masing-masing yaitu $0,626 \%$, $3,243 \%, \quad 7,880 \%, \quad 8,010 \%, \quad 8,088 \%$, $8,658 \%$ dan $8,450 \%{ }^{2}$. Sementara pada penelitian tentang analisis kadar alkohol pada tuak lontar dalam berbagai variasi waktu penyimpanan diperoleh kadar ratarata alkohol pada tuak lontar yang disimpan pada hari pertama $7,32 \%$, hari kedua 7,53\%, hari ketiga 7,61\%, hari keempat $7,23 \%$, dan hari kelima $7,11 \%$. Berdasarkan penelitian tersebut dapat diketahui bahwa lama penyimpanan mempengaruhi kadar etanol pada tuak.

Lama penyimpanan juga mempengaruhi salah satu karakteristik subjektif dari tuak berupa rasa. Tuak segar yang baru menetes dari pohonnya memiliki pH netral sekitar 7 akan tetapi pengaruh keadaan lingkungan sekitar menyebabkan tuak mudah terkontaminasi dan menyebabkan $\mathrm{pH}$ menurun sehingga rasa manis berubah asam ${ }^{4}$. Berdasarkan uraian tersebut peneliti ingin melakukan penelitian pada tuak aren yang dikonsumsi oleh masyarakat Bali dengan waktu penyimpanan yang berbeda dengan menilai karakteristik tuak aren tersebut secara objektif dan subjektif.

Jenis penelitian ini termasuk dalam rancangan eksperimen semu (quasi 14

Meditory | ISSN Online : 2549-1520, ISSN Cetak : 2338 - 1159, Vol. 5, No.1, Juni 2017 HIm. $13-22$, http://ejournal.poltekkes-denpasar.ac.id 
A. A. Ayu Trisna Pradnyandari, dkk., Kajian Karakteristik Objektif Dan Subjektif Tuak Aren (Arenga pinnata) Berdasarkan Lama Waktu Penyimpanan

experiment design). Lokasi penelitian dilakukan di dua tempat yaitu di Laboratorium Kimia Analisis Farmasi Jurusan Farmasi Fakultas MIPA Universitas Udayana dan Laboratorium Kimia Jurusan Analis Kesehatan Poltekkes Denpasar. Pengukuran kadar etanol pada tuak aren dilakukan di Laboratorium Kimia Analisis Farmasi Jurusan Farmasi Fakultas MIPA Universitas Udayana, sementara pengukuran $\mathrm{pH}$ dan kadar total asam pada tuak aren dilakukan di Laboratorium Kimia Jurusan Analis Kesehatan Poltekkes Denpasar. Penelitian ini dilaksanakan pada bulan Januari sampai Juli 2016.

Populasi pada penelitian ini adalah tuak aren yang berada di desa Bongkasa,

\section{HASIL DAN PEMBAHASAN}

\section{Karakteristik objek penelitian}

Penilaian karakteristik sampel tuak aren menggunakan uji organoleptik. Uji organoleptik pada sampel tuak aren kabupaten Badung. Penelitian ini dilakukan dengan menggunakan lima pengamatan sehingga diperoleh jumlah data sebanyak lima data. Sampel sesuai kriteria yang sudah ditetapkan yaitu tuak aren segar yang baru disadap dan siap dikonsumsi. Sampel tuak aren disimpan pada suhu ruang $\left(24-30^{\circ} \mathrm{C}\right)$ pada hari pertama, kedua, ketiga, keempat, dan kelima. Penelitian dilakukan dengan menilai karakteristik objektif dan subjektif tuak aren yang meliputi pengukuran kadar etanol menggunakan Gas Cromatografi (GC), pengukuran $\mathrm{pH}$ menggunakan kertas $\mathrm{pH}$, pengukuran kadar total asam dengan metode titrasi, serta uji organoleptik dengan 15 orang panelis dengan metode uji tingkat penerimaan.

dilakukan pada sore hari dengan pembagian kuesioner pada panelis dengan metode uji penerimaan yang meliputi rasa, warna, dan aroma tuak aren berdasarkan lama waktu penyimpanan.

Tabel 1

Penilaian Organoleptik Tuak Aren

\begin{tabular}{ccccc}
\hline No. & $\begin{array}{c}\text { Waktu } \\
\text { Penyimpanan }\end{array}$ & Rasa & Warna & Aroma \\
\hline 1 & Hari I & Manis agak & Cokelat muda & Segar \\
& & asam & & \\
2 & Hari II & Asam & Cokelat muda & Asam \\
& & & agak pucat & \\
3 & Hari III & Sangat asam & Cokelat muda & Asam agak
\end{tabular}

Meditory | ISSN Online : 2549-1520, ISSN Cetak : 2338 - 1159, Vol. 5, No.1, Juni 2017 
A. A. Ayu Trisna Pradnyandari, dkk., Kajian Karakteristik Objektif Dan Subjektif Tuak Aren (Arenga pinnata) Berdasarkan Lama Waktu Penyimpanan

\begin{tabular}{|c|c|c|c|c|}
\hline \multirow{3}{*}{4} & & & sangat pucat & menyengat \\
\hline & Hari IV & Asam agak & Putih agak & Asam sangat \\
\hline & & pahit & kecokelatan & menyengat \\
\hline 5 & Hari V & Sangat pahit & Putih kecokelatan & Asam agak busuk \\
\hline
\end{tabular}

\section{Hasil Pengamatan}

Hasil pemeriksaan kadar etanol

pada tuak aren pada penyimpanan hari pertama, hari kedua, hari ketiga, hari

keempat, dan hari kelima dapat dilihat

pada diagram berikut:

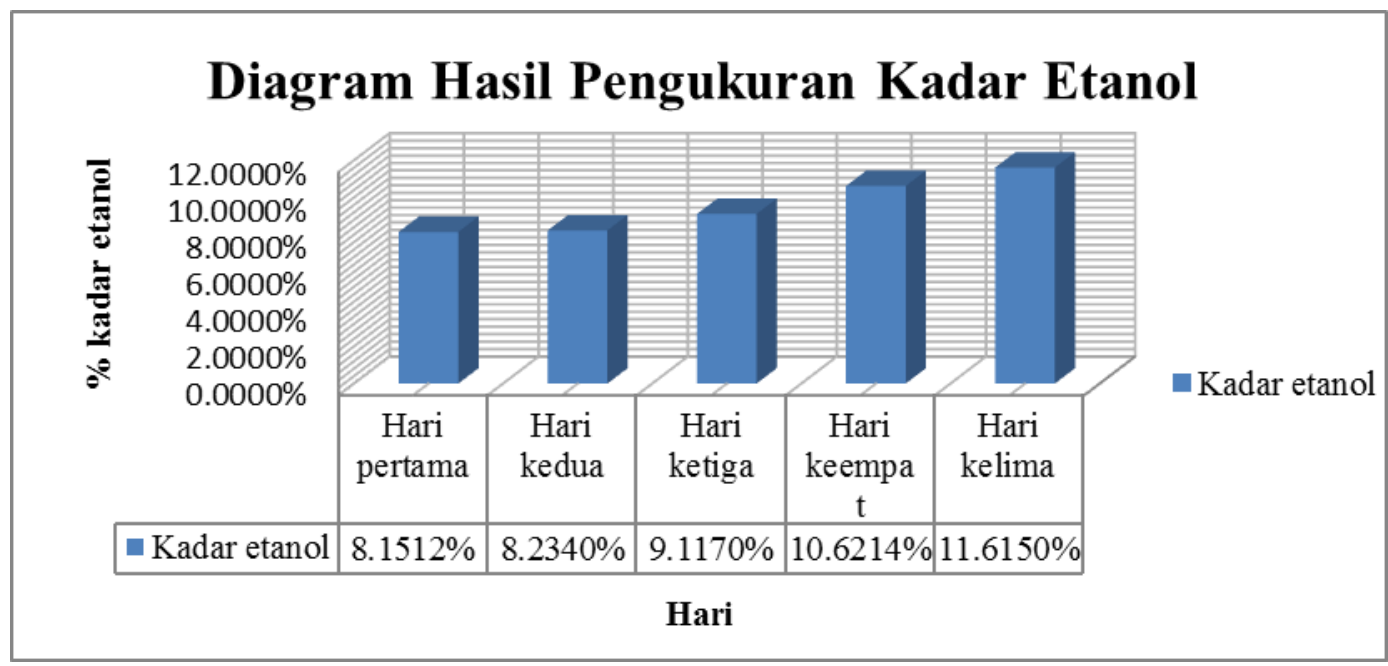

Gambar 1. Diagram Hasil Pengukuran Kadar Etanol

Berdasarkan diagram diatas, dapat dilihat bahwa kadar etanol tuak aren hasil penyimpanan pada hari pertama hingga hari kelima terus mengalami peningkatan.

Tabel 2

pH Tuak Aren

\begin{tabular}{ccc}
\hline No. & Waktu Penyimpanan & $\mathrm{pH}$ \\
\hline 1 & Hari I & 4 \\
2 & Hari II & 4 \\
3 & Hari III & 4 \\
4 & Hari IV & 4 \\
5 & Hari V & 4 \\
\hline
\end{tabular}

Berdasarkan tabel dapat dilihat penyimpanan pada hari pertama, hari bahwa $\mathrm{pH}$ tuak aren dengan waktu kedua, hari ketiga, hari keempat, dan hari 
A. A. Ayu Trisna Pradnyandari, dkk., Kajian Karakteristik Objektif Dan Subjektif Tuak Aren (Arenga pinnata) Berdasarkan Lama Waktu Penyimpanan

kelima memiliki $\mathrm{pH}$ yang sama. $\mathrm{pH}$ yang dihasilkan adalah 4. Hasil pengukuran $\mathrm{pH}$ tersebut menunjukkan tuak aren dengan waktu penyimpanan pada hari pertama, hari kedua, hari ketiga, hari keempat, dan hari kelima bersifat asam.

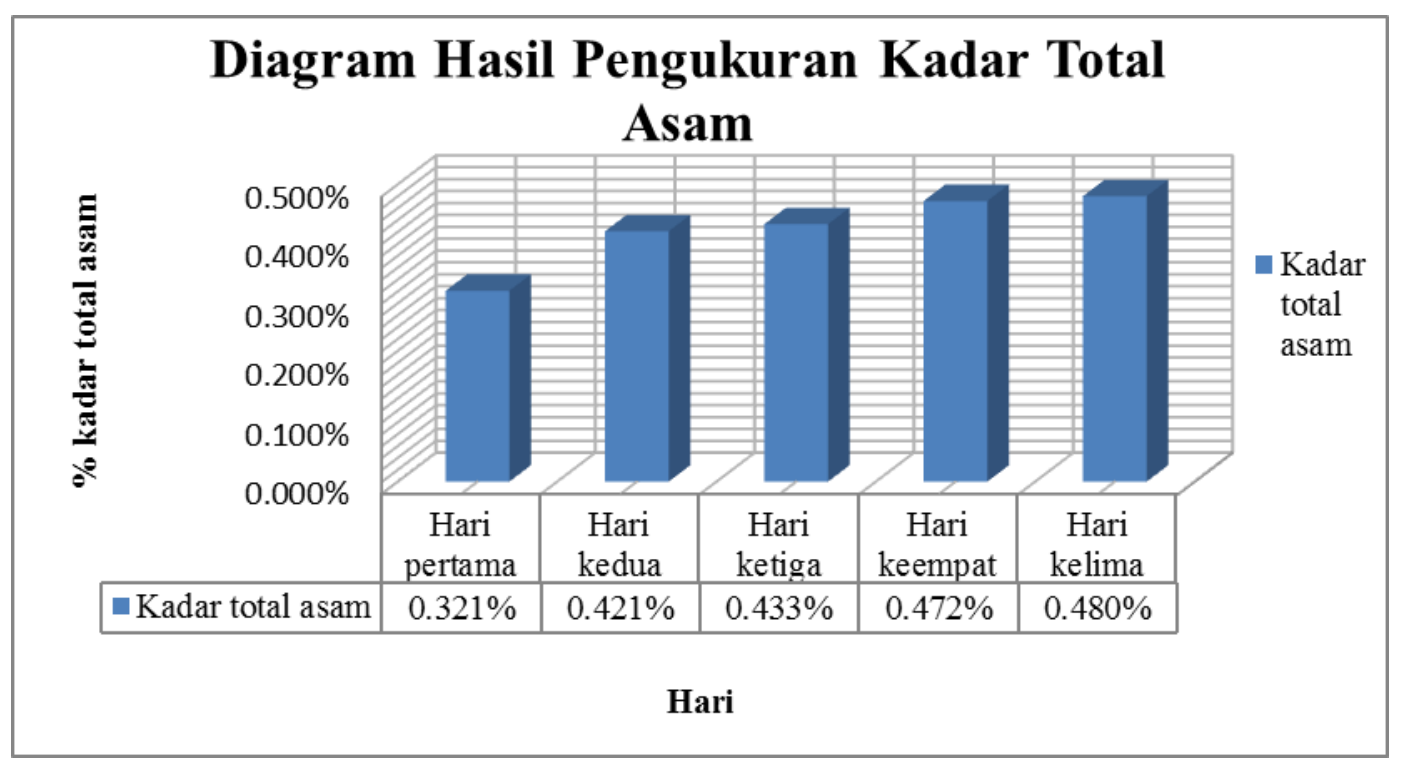

Gambar 2. Diagram Hasil Pengukuran Kadar Total Asam

Kadar total asam tuak aren hasil penyimpanan hari pertama hingga hari kelima terus mengalami peningkatan.

\section{PEMBAHASAN}

Kadar etanol pada tuak aren yang diukur berdasarkan lama penyimpanan mengalami peningkatan. Tuak aren dengan waktu penyimpanan pada hari pertama diperoleh kadar etanol sebesar 8,1512\%. Tuak aren yang mengalami penyimpanan pada hari kedua memiliki kadar etanol sebesar $8,234 \%$. Jika dibandingkan dengan kadar etanol pada tuak aren dengan penyimpanan pada hari pertama terjadi peningkatan kadar etanol sebesar $0,0828 \%$. Pada tuak aren yang mengalami penyimpanan dalam suhu ruang pada hari ketiga diperoleh kadar etanol sebesar 9,117\%. Dibandingkan dengan kadar etanol pada hari kedua terjadi peningkatan kadar etanol sebesar 0,883\%. Pada tuak aren yang mengalami penyimpanan dalam suhu ruang pada hari keempat diperoleh kadar etanol sebesar 10,6214\%. Dibandingkan dengan kadar etanol pada hari ketiga terjadi peningkatan kadar etanol sebesar $1,5251 \%$. Peningkatan yang terjadi cukup besar dibandingkan hari lainnya, hal ini terjadi karena pada waktu penyimpanan ini mikroba pada tuak aren mengalami pertumbuhan yang maksimal, dimana pada fase ini kondisi dari tuak aren yang mengalami penyimpanan pada suhu

Meditory | ISSN Online : 2549-1520, ISSN Cetak : 2338 - 1159, Vol. 5, No.1, Juni 2017 HIm. 13 - 22, http://ejournal.poltekkes-denpasar.ac.id 
A. A. Ayu Trisna Pradnyandari, dkk., Kajian Karakteristik Objektif Dan Subjektif Tuak Aren (Arenga pinnata) Berdasarkan Lama Waktu Penyimpanan

$24-30^{\circ} \mathrm{C}$ yang merupakan suhu optimum dari pertumbuhan khamir sehingga mikroba dapat menggunakan nutrisi dalam medium fermentasinya dengan baik dan pada fase ini mikroba banyak tumbuh dan membelah diri sehingga jumlahnya meningkat dengan cepat ${ }^{5}$.

Tuak aren yang mengalami penyimpanan di suhu ruang pada hari kelima diperoleh kadar etanol sebesar 11,615\%. Dibandingkan dengan kadar etanol pada hari keempat terjadi peningkatan kadar etanol sebesar 0,9936\%. Peningkatan kadar yang terjadi pada hari kelima lebih rendah dibandingkan dengan peningkatan kadar etanol pada hari keempat. Hal tersebut disebabkan oleh akhir pertumbuhan mikroba pada tuak aren ini, yang merupakan fase eksponensial dimana fase ini laju pertumbuhan tetap pada laju pertumbuhan maksimum ${ }^{2}$. Berdasarkan hasil penelitian tersebut dapat diketahui kadar etanol pada tuak aren yang telah mengalami penyimpanan dari hari pertama hingga hari kelima berkisar pada $8-12 \%$ sehingga tuak aren tersebut termasuk kedalam minuman keras golongan B.

Proses fermentasi dari tuak aren dipengaruhi oleh beberapa faktor yang salah satunya adalah $\mathrm{pH}$. $\mathrm{pH}$ tuak aren dengan waktu penyimpanan pada hari pertama, hari kedua, hari ketiga, hari keempat, dan hari kelima memiliki $\mathrm{pH}$ yang sama yaitu 4. Hasil pengukuran $\mathrm{pH}$ tersebut menunjukkan tuak aren dengan waktu penyimpanan pada hari pertama, hari kedua, hari ketiga, hari keempat, dan hari kelima berada dalam suasana asam. Dalam suasana asam tersebut hingga hari kelima pertumbuhan khamir masih berlangsung sehingga proses fermentasi masih terjadi. Pertumbuhan khamir dapat berlangsung baik pada suasana asam yaitu pada $\mathrm{pH} 4,0-4,5^{5}$. $\mathrm{pH}$ tuak aren yang rendah dapat mengakibatkan dampak negatif bagi kesehatan gigi apabila dikonsumsi terus-menerus ${ }^{6}$.

Berdasarkan hasil penelitian, tuak aren dengan waktu penyimpanan pada hari pertama memiliki kadar total asam yang paling rendah yaitu $0,321 \%$. Kadar total asam tuak aren pada penyimpanan hari kedua yaitu $0,421 \%$. Jika dibandingkan dengan kadar total asam pada tuak aren dengan penyimpanan pada hari pertama terjadi peningkatan kadar total asam sebesar $0,1 \%$. Kadar total asam tuak aren pada penyimpanan hari ketiga yaitu 0,433\%. Dibandingkan dengan kadar total asam pada tuak aren dengan penyimpanan pada hari kedua terjadi peningkatan kadar total asam sebesar 0,012\%. Kadar total asam tuak aren pada penyimpanan hari keempat yaitu $0,472 \%$. Dibandingkan dengan kadar total asam pada tuak aren 
A. A. Ayu Trisna Pradnyandari, dkk., Kajian Karakteristik Objektif Dan Subjektif Tuak Aren (Arenga pinnata) Berdasarkan Lama Waktu Penyimpanan

dengan penyimpanan pada hari ketiga terjadi peningkatan kadar total asam sebesar 0,039\%. Tuak aren pada penyimpanan hari kelima memiliki kadar total asam yang paling tinggi yaitu 0,480\%. Jika dibandingkan dengan kadar total asam pada tuak aren dengan penyimpanan pada hari keempat terjadi peningkatan kadar total asam sebesar $0,008 \%$. Tuak aren mengandung gula yang merupakan komponen utama sebagai sumber energi bagi mikroba. Dari hasil penelitian dapat dilihat bahwa kadar total asam tuak aren hasil penyimpanan hari pertama hingga hari kelima terus mengalami peningkatan. Hal tersebut disebabkan oleh fermentasi yang terjadi pada tuak aren. Pada tuak terjadi fermentasi laktat alkohol asetat yang merupakan fermentasi spontan dimana melibatkan bakteri asam laktat, khamir, dan bakteri asam asetat. Leuconostoc spp dan Lactobacillus spp merupakan mikroorganisme awal yang terdapat di dalam nira segar yang diduga merupakan mikroorganisme dominan pada nira yang merupakan bahan dari pembuat tuak aren. Saccharomyces cereviceae adalah khamir yang biasa melakukan fermentasi alkohol ${ }^{7}$. Bakteri asam laktat dan khamir bekerja secara bersama dalam proses fermentasi tuak. Jika proses fermentasi tuak dibiarkan dan berlangsung terus, akan terbentuk asam cuka yang rasanya asam ${ }^{8}$.

Berdasarkan hasil penilaian uji organoleptik, tuak aren pada penyimpanan hari pertama memiliki rasa manis agak asam sehingga meninggalkan kesan menyegarkan di tenggorokan. Rasa manis tersebut disebabkan oleh kandungan sukrosa yang terdapat pada tuak aren walaupun sudah mulai berkurang karena proses fermentasi. Hasil dari penilaian rasa oleh kelimabelas panelis yang mencicipi tuak aren yang disimpan pada hari pertama yaitu kelima panelis menyatakan suka pada rasa tuak aren tersebut.

Tuak aren pada penyimpanan hari kedua memiliki rasa asam sehingga hanya 2 panelis yang menyukai rasa dari tuak aren tersebut. Rasa asam tersebut disebabkan oleh kecepatan fermentasi yang terjadi pada tuak sehingga kadar gula menurun, karena sebagian gula dirombak oleh enzim yang dihasilkan dari proses fermentasi menjadi asam dan alkohol. Kejadian ini menyebabkan tuak aren menjadi masam (kecut). Rasa tuak aren pada penyimpanan hari ketiga semakin asam sementara pada hari keempat rasa dari tuak aren sudah mulai agak pahit dan pada hari kelima rasa tuak aren sangat pahit. Hal tersebut menyebabkan tuak aren pada penyimpanan hari ketiga hingga hari kelima tidak disukai oleh kelima panelis.

Meditory | ISSN Online : 2549-1520, ISSN Cetak : 2338 - 1159, Vol. 5, No.1, Juni 2017 
A. A. Ayu Trisna Pradnyandari, dkk., Kajian Karakteristik Objektif Dan Subjektif Tuak Aren (Arenga pinnata) Berdasarkan Lama Waktu Penyimpanan

Semakin lama penyimpanan maka kadar gula pada tuak akan semakin menurun sehingga rasa dari tuak akan semakin asam dan pahit.

Perubahan warna dari tuak aren dari penyimpanan hari pertama hingga hari kelima tidak terlalu signifikan. Hanya warna tuak yang awalnya cokelat muda berubah semakin pucat selama mengalami penyimpanan. Warna cokelat tersebut diperoleh dari pengawet alami tuak yaitu lau (sabut kelapa). Warna dari tuak aren penyimpanan hari pertama disukai oleh kelima panelis karena warnanya yang menarik. Sementara pada hari kedua hanya tiga panelis yang menyukai warna dari tuak aren dan mulai dari hari ketiga hingga hari kelima semua panelis tidak menyukai warna tuak aren yang sudah mengalami perubahan menjadi putih kecoklatan. Warna dari tuak aren tersebut tidak disukai karena sudah dianggap tidak menarik oleh panelis.

Pada hasil uji organoleptik, aroma tuak aren yang awalnya segar pada hari pertama mulai mengalami perubahan aroma menjadi asam pada penyimpanan hari kedua. Aroma asam tersebut disebabkan karena pada tuak yang difermentasi, mikroba proteolitik dan lipolitik tidak berkembang dengan baik karena konsentrasi alkohol dan asam yang lebih tinggi, sehingga aroma yang lebih dominan adalah aroma alkohol yang agak asam. Aroma asam dari tuak aren semakin menyengat pada hari ketiga hingga hari keempat dan pada hari kelima aroma tuak aren menjadi agak busuk. Hal tersebut disebabkan oleh mikroba proteolitik pada tuak aren menghasilkan bau busuk dengan memecah protein dan komponen nitrogen, sedangkan mikroba lipolitik memecah serta menghidrolisa lemak dan fosfolipid sehingga menghasilkan bau tengik ${ }^{9}$. Aroma dari tuak aren penyimpanan hari pertama disukai oleh kelima panelis. Sementara pada hari kedua hanya dua panelis yang menyukai aroma dari tuak aren dan mulai dari hari ketiga hingga hari kelima semua panelis tidak menyukai aroma tuak aren yang sudah mengalami perubahan.

Peningkatan kadar etanol tuak aren tidak terlalu signifikan tetapi besarnya kadar etanol menjadikan tuak aren tersebut termasuk kedalam minuman keras golongan B yang dapat menimbulkan dampak negatif apabila dikonsumsi secara berlebihan dan terus-menerus. Selain itu, $\mathrm{pH}$ tuak aren yang asam apabila dikonsumsi secara berlebihan dan terusmenerus juga dapat menimbulkan dampak negatif bagi kesehatan gigi. Akan tetapi dengan penyimpanan tuak aren menyebabkan proses fermentasi pada tuak tetap berlangsung dan akan terbentuk asam 
A. A. Ayu Trisna Pradnyandari, dkk., Kajian Karakteristik Objektif Dan Subjektif Tuak Aren (Arenga pinnata) Berdasarkan Lama Waktu Penyimpanan

cuka yang ditunjukkan dengan peningkatan kadar total asam pada tuak aren selama mengalami penyimpanan ${ }^{8}$. Asam cuka yang dihasilkan tuak aren tersebut membuat tuak aren dapat dimanfaatkan menjadi cuka. Selain dimanfaatkan sebagai cuka, etanol yang dihasilkan tuak aren juga dapat membuat tuak aren dimanfaatkan sebagai bahan pembuatan bioethanol.

\section{SIMPULAN DAN SARAN}

\section{Simpulan}

1. Kadar etanol tuak aren hasil penyimpanan pada hari pertama hingga hari kelima terus mengalami peningkatan yaitu $8,1512 \%, 8,234 \%$, $9,117 \%, 10,6214 \%$, dan $11,615 \%$.

2. $\mathrm{pH}$ tuak aren dengan waktu penyimpanan pada hari pertama hingga hari kelima memiliki $\mathrm{pH}$ yang sama yaitu 4. Hasil pengukuran $\mathrm{pH}$ tersebut menunjukkan tuak aren bersifat asam.

3. Kadar total asam tuak aren hasil penyimpanan pada hari pertama hingga hari kelima terus mengalami peningkatan yaitu $0,321 \%, 0,421 \%$, $0,433 \%, 0,472 \%$, dan $0,480 \%$.

4. Dari hasil uji organoleptik, tuak aren yang paling disukai baik dari segi rasa, warna, dan aroma adalah tuak aren dengan waktu penyimpanan pada hari pertama.

\section{Saran}

1. Bagi konsumen disarankan untuk tidak mengkonsumsi tuak aren yang telah mengalami penyimpanan karena telah terjadi perubahan karakteristik objektif maupun subjektif. Kadar etanol yang semakin mengalami peningkatan dapat menimbulkan dampak negatif bagi kesehatan dan dari segi rasa yang semakin asam.

2. Bagi pemerintah khususnya Dinas Kesehatan dan Badan Pengawas Obat dan Makanan (BPOM) untuk selalu memantau penjualan tuak aren karena tuak aren tersebut sudah termasuk kedalam minuman keras golongan B yang hanya dapat diedarkan di hotel, bar, restoran, dan toko bebas bea yang persyaratannya ditetapkan oleh Kementerian Pariwisata dan Ekonomi Kreatif.

3. Bagi peneliti selanjutnya disarankan untuk lebih mengembangkan karya tulis ini dengan menggunakan $\mathrm{pH}$ meter digital sebagai alat untuk melakukan pengukuran $\mathrm{pH}$, sehingga diperoleh hasil yang lebih akurat.

\section{DAFTAR PUSTAKA}

1. Keputusan Presiden Republik Indonesia Nomor 3 Tahun 1997 tentang Pengawasan dan Pengendalian Minuman Beralkohol. 
A. A. Ayu Trisna Pradnyandari, dkk., Kajian Karakteristik Objektif Dan Subjektif Tuak Aren (Arenga pinnata) Berdasarkan Lama Waktu Penyimpanan

2. Sholikhah, S. M. 2010. Kajian Kadar Etanol Dan Asam Asetat Dalam Cairan Nira Siwalan (Borassus Flabellifer Linn) Menggunakan Metode Kromatografi Gas (GC). Malang: Jurusan Kimia Fakultas Sains Dan Teknologi Universitas Islam Negeri (UIN) Maulana Malik Ibrahim Malang.

3. Nuradi. 2013. Analisis Kadar Alkohol Pada Tuak Lontar (Borassus flabellifer L.) Dalam Berbagai Variasi Waktu Penyimpanan. Makassar: Politeknik Kesehatan Makassar.

4. Noviyanti, R. 2014. Pengaruh Konsumsi Minuman Tuak Terhadap Erosi Gigi Di Kecamatan Maiwa Kabupaten Enrekang. Makassar: Universitas Hasanuddin.

5. Fardiaz, S. 1992. Mikrobiologi Pangan 1. Jakarta: PT. Gramedia Utama Pustaka.
6. Prasetyo. 2005. Keasaman Minuman Ringan Menurunkan Kekerasan Permukaan Gigi. tersedia dalam http://www.journal.unair.ac.id/filer PDF/DENTJ-38-2-04.pdf diakses pada 9 Juni 2016.

7. Lubis, R. F., R. J. Nainggolan, dan M. Numinah. 2013. Pengaruh Penambahan Konsentrasi Bahan Pengawet Alam Pada Nira Aren Selama Penyimpanan Terhadap Mutu Gula Aren Cair. Medan: Fakultas Pertanian USU.

8. Sunanto, H. 1993. Aren Budidaya dan Multigunanya. Yogyakarta: Kanisius.

9. Mussa, R. 2014. Kajian Tentang Lama Fermentasi Nira Aren (Arenga pinnata) Terhadap Kelimpahan Mikroba dan Kualitas Organoleptik Tuak. Ambon: Universitas Pattimura. 